\title{
Study on lysozyme activity in some fish species
}

\author{
Øystein Lie, Øystein Evensen, Anita Sørensen, Ellen Frøysadal
}

National Veterinary Institute, PO Box 8156 Dep, N-0033 Oslo 1, Norway

\begin{abstract}
Lysozyme activity was studied in various species of fish (13 wild species and cultured rainbow trout Salmo gaairdneri and Atlantic salmon Salmo salar). Marked interspecies variation prevailed, most strikingly between rainbow trout and Atlantic salmon; lysozyme activity in the former was at least 20 times greater than in the latter. Tissue distribution was studied in more depth in rainbow trout. Kidneys appeared to have the highest lysozyme levels, followed in descending order by alimentary tract, spleen, skin mucus, serum, gills, liver and muscle. This pattern is compatible with the assumption that lysozymes play an important role in body defence. Using gel filtration chromatography, 2 lysozyme-like variants with molecular weights (MW) of ca 14500 (high activity) and 23000 daltons (low activity) were found in rainbow trout kidney. Only low MW activities (between 13000 and 12000 daltons) were detected in Atlantic salmon. Relevant future research approaches, as well as possible or speculative applications of lysozymes in disease control, are discussed.
\end{abstract}

\section{INTRODUCTION}

Although immune systems in fish comprise major factors possessed by higher vertebrates, they also display differences or 'limitations', especially in antibodydependent immunity. (1) The immune response is very sensitive to stress and temperature variations; in Norway, farmed fish are mainly kept at fairly low temperature $\left(2\right.$ to $\left.15^{\circ} \mathrm{C}\right)$ and, in many cases, under crowded conditions which cause stress. (2) In respect of antibody diversity, fish possess a somewhat restricted repertoire due to a gene arrangement which differs from that in higher vertebrates. Moreover, the number of immunoglobulin isotypes ( 1 or 2 ) is also probably quite limited compared to higher vertebrates (Ellis 1981, 1982, Du Pasquier 1982, Tonegawa 1983, Matsunaga 1985).

For genetic improvement of fish with regard to resistance to infection it is therefore of interest to study nonspecific defence mechanisms. These include, as in higher vertebrates, a wide spectrum of cellular and non-cellular (soluble) factors, one of which is lysozyme (for review see Ingram 1980). In higher vertebrates, lysozymes are involved in a broad battery of defence mechanisms, embracing actions such as bacteriolysis, opsonization, immune response potentiation as well as restricted anti-viral and antineoplastic activity (for review see Jolles \& Jolles 1984, Lie \& Syed 1986). In addition to their defence role, lysozymes have digestive tasks (Dobson et al. 1984). Genetic factors involved in controlling the levels of lysozymes have also been revealed. A dominant gene for high lysozyme activity has been detected in cattle (Lie \& Solbu 1983). Moreover, a corresponding low-level recessive gene has been found in rabbits (Prieur \& Camara 1979), and positive and negative regulatory genes, i.e. enhancers and silencers, of chicken lysozyme have been isolated, cloned and their expression studied by transfection experiments in chicken cell lines (Theisen et al. 1986. Baniahmad et al. 1987, Steiner et al. 1987). Several studies indicate that lysozyme may play a role in fish as a defence mechanism against infectious disease (Fänge et al. 1976, Murray \& Fletcher 1976, Lundblad et al. 1979, Lindsay 1986).

We have performed a study on lysozyme activity in certain fish species, with special reference to tissue distribution and partial characterization of lysozymes in rainbow trout.

\section{MATERIAL AND METHODS}

We investigated specimens of rainbow trout Salmo gairdneri and Atlantic salmon S. salar, submitted to the National Veterinary Institute, Department of Aquaculture and Fish Diseases and constituting about 40 and 50 healthy individuals of each species. The fish had a mean weight of 2.5 and $1.0 \mathrm{~kg}$, and averaged 30 and 22 mo of age. In addition, a few individuals from each of 13 wild species of fish were most generously supplied by a fish industry company located in western Norway. 
The wild species (except for the shark Galeorhinus galeus) were of size and weight normal for sale.

Turbidimetric assay was carried out according to Parry et al. (1965) with some modification. Briefly, $2 \mathrm{ml}$ of a Micrococcus lysodeikticus suspension, $0.20 \mathrm{mg}$ per $\mathrm{ml}$ $0.05 \mathrm{M}$ sodium phosphate buffer $\mathrm{pH}=6.2$, was mixed with varying amounts of lysozyme source, the actual amount, usually $10 \mu \mathrm{l}$, depending upon the strength of the source. The decrease in absorbance (delta A) per min was recorded at $520 \mathrm{~nm}$ and at room temperature, 1 unit being defined as giving delta $\mathrm{A} \mathrm{min}{ }^{-1}=0.001$

Lysoplate assay was run as described by Osserman \& Lawlor (1966) with some modifications, and using a modified Gram-staining preservation technique developed by Lie et al. (1986). The method is based on lysis of the standard bacterium Micrococcus lysodeikticus in $1 \%$ agarose prepared in $0.05 \mathrm{M}$ sodium phosphate buffer $\mathrm{pH}=6.2$. The diameters of the lysed zones, visualized by lack of color in contrast to the blue unlysed area, were determined by a Measuring-viewer (Behringwerke) and transformed to lysozyme diffusion units (i.e. reciprocal value of the dilution factor corresponding to the end point of a 2 -fold titration), $\log$ of the activity being proportional to the diameter.

Lysorocket electrophoresis was run according to Virella (1977) with some modification employing a staining technique as developed for the lysoplate (Lie et al. 1986). A $1 \%$ agarose gel in $0.05 \mathrm{M}$ barbital sodium barbital buffer $\mathrm{pH}=8.2$, containing $50 \mu \mathrm{g} \mathrm{ml}^{-1}$ of Micrococcus lysodeikticus, was prepared on $10 \times 10$ $\mathrm{cm}$ glass slides. The samples were applied into a row of wells placed in the middle of the plate. Samples were run overnight at 1.2 to 1.5 volts per $\mathrm{cm}$ agar at $25^{\circ} \mathrm{C}$, lysozyme activity appearing as colorless rockets on a stained background.

Heat stability test was performed as described by Lie \& Syed (1986). Briefly, $\left(\mathrm{NH}_{4}\right)_{2} \mathrm{SO}_{4}$ precipitated samples (see below) from Atlantic salmon and rainbow trout were each divided into 2 aliquots, one of which was equilibrated with $50 \mathrm{mM}$ Tris/HCI $\mathrm{pH}=4$, the other with the same buffer at $\mathrm{pH}=9$. Equilibration was performed on PD-10 (Sephadex G-25, Pharmacia) columns for buffer exchange and desalting. Samples were heated in glass tubes on water bath at $100{ }^{\circ} \mathrm{C}$ for 20 min. Small samples were drawn from each tube before heating and at regular intervals during heating and placed on ice before assayed on lysoplates.

Fractionation of lysozyme-containing tissues. Pooled kidney from each of the 15 species was homogenized in 4 parts of phosphate buffer $150 \mathrm{mM}$, $\mathrm{pH}=6.2$ ). This was centrifuged for $30 \mathrm{~min}$ at $30000 \times g$ and $4{ }^{\circ} \mathrm{C}$ after which the pellet was discarded and the supernatant subjected to acidic precipitation with $2.5 \mathrm{M}$ acetic acid to $\mathrm{pH}=4.5$. After a second centrifugation $\left(10000 \times g, 15 \mathrm{~min}, 4^{\circ} \mathrm{C}\right)$, the supernatant was collected, neutralized by adding $1.0 \mathrm{M} \mathrm{NaOH}$, and subjected to fractional precipitation by 35 to $85 \%$ saturation of $\left(\mathrm{NH}_{4}\right)_{2} \mathrm{SO}_{4}$ at $4{ }^{\circ} \mathrm{C}$. This cut was optimized by calculating lysozyme recovery for various cut trials. The $85 \%$ precipitate was redissolved in $50 \mathrm{mM}$ Tris/ $\mathrm{HCl}$ buffer $\mathrm{pH}=7.4$ until a clear solution was obtained. The 35 to $85 \%$ saturation cut from kidney of each species was desalted and equilibrated to the assay buffer $(0.05 M$ sodium phosphate, $\mathrm{pH}=6.2$ ) on $\mathrm{PD}-10$ columns before being subjected to activity studies. The extra tissues investigated in rainbow trout were treated as described for the kidney. Serum and diluted mucus were subjected to direct $\left(\mathrm{NH}_{4}\right)_{2} \mathrm{SO}_{4}$ precipitation without any prior homogenization.

Gel filtration. The 35 to $85 \%$ saturation cut was applied to a column of Ultrogel ACA $54(38 \times 2.6)$ with a linear fractionation range $\mathrm{MW}$ from 5000 to 70000 (Reactifs IBF). The column was equilibrated with the above buffer, which was also employed for the elution. A low MW Kit (Pharmacia) was used for calibration. The distribution coefficient $K_{a v}$ was plotted against $\log _{10} \mathrm{MW}$ of the Kit proteins. This gave a linear equation (with correlation coeffiecient of $r=0.99$ ) from which MW of lysozyme activity was estimated. Fractions of $2 \mathrm{ml}$ each were collected; lysozyme activity was measured by the turbidimetric method, protein by OD at $280 \mathrm{~nm}$. All fractions were prescreened for lysozyme activity by the rapid and sensitive lysoplate method

\section{RESULTS AND DISCUSSION}

\section{Some properties of rainbow trout and Atlantic salmon lysozymes}

The elution diagram after separation by size (Fig. 1) and the calibration curve (not given) showed that the main lysozyme activity in both rainbow trout and Atlantic salmon was associated with a molecular weight (MW) of ca 12000 to 15000 daltons. This corresponds to the classical type (c-type) lysozyme found in birds and mammals. Within this size range, rainbow trout displayed a variant of $14.5 \mathrm{kD}$, while Atlantic salmon exhibited activities associated with MW between 12.0 and $13.0 \mathrm{kD}$. Further, rainbow trout showed one variant of ca $23 \mathrm{kD}$, whereas Atlantic salmon revealed no significant activity within the high MW range (19 to $23 \mathrm{kD}$ ). The latter finding may be attributable to detection problems because of the relatively low lysozyme levels in this species. Moreover, low MW variants may be hidden in the high activity fraction of rainbow trout lysozymes. Further biochemical studies are now in progress to clarify these points, as well as the question as to whether or not the activities uncovered are true lysozymes (E.C.3.2.1.17) 
Fig. 1. Salmo gairdneri and S. salar. Typical elution diagrams for lysozymes obtained by a single gel-filtration of a 35 to $85 \%$ $\left(\mathrm{NH}_{4}\right)_{2} \mathrm{SO}_{4}$ precipitation of homogenized kidney. Lysozyme activity given in turbidimetric units (delta $\mathrm{A} \times 1000 \times \mathrm{min}^{-1}$ $\mathrm{ml}^{-1}$ ). Eluted fractions were also prescreened by the lysoplate method

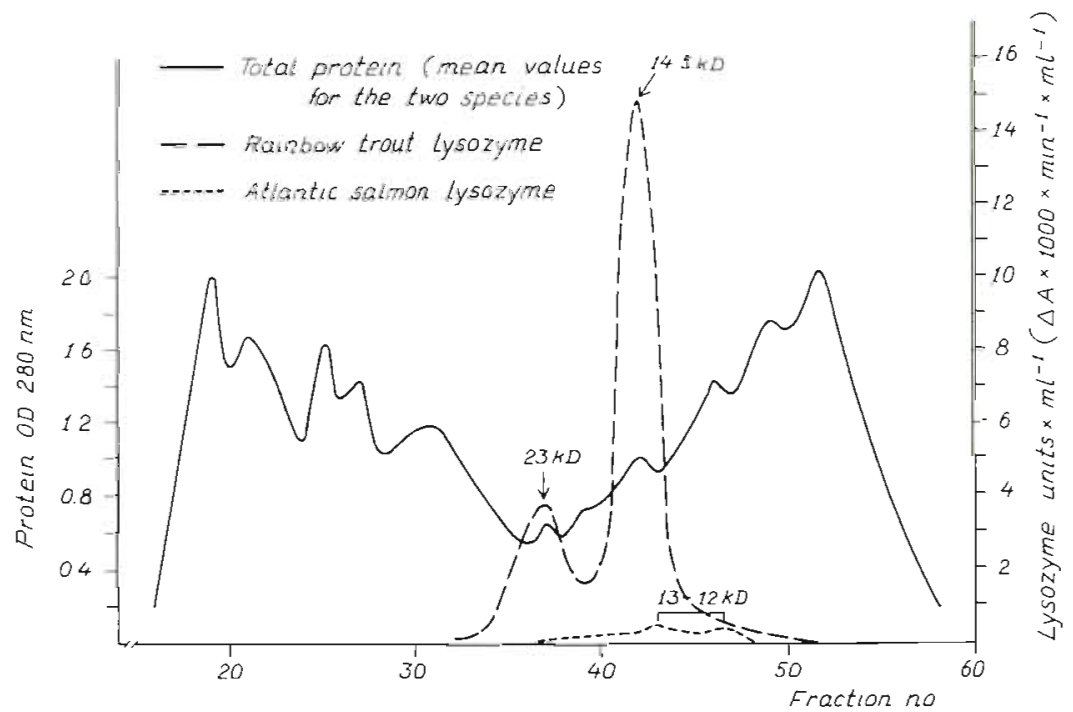

studies in progress in which immunoassays will be employed for direct determination of concentrations.

\section{Tissue distribution}

Our findings on tissue distribution in rainbow trout (Table 1) indicate that lysozyme activity is associated with tissues normally rich in leucocytes (kidney, spleen, alimentary tract, etc.). These findings were not unexpected since monocytes, macrophages and polymorphonucleated granulocytes are thought to be the main sources of lysozyme. The close association with cells of the immune system may indicate that the enzyme contributes to defence against infectious diseases. However, the high levels in tissues subject to high microbial invasion (mucus, gills, alimentary tract), emphasize the defence role of lysozyme, especially in first-line defence mechanisms. Our results were also consistent with findings of Lindsay (1986), except for the relative content of lysozyme in kidney and alimentary tract. However, this may be explained by the fact

Table 1. Salmo gairdneri. Lysozyme activity in tissues measured by turbidimetric assay on diffusion and lysis, and thus dependent on size and concentration of molecules, affinity to the matrix as well as the specific activity of the enzymes. This emphasizes the importance of distinguishing between specific activity and amount of lysozyme. Nevertheless, comparing rainbow trout to Atlantic salmon, the former was strongly superior in both the turbidimetric and lysoplate assay. Within-species variation is probably due to different concentrations of lysozyme molecules (regulatory genes) and thus correspondingly reflected in both assays. This will be clarified by

\begin{tabular}{|lr|}
\hline Tissue & Lysozyme units $\mathrm{g}^{-1} \pm \mathrm{SE}$ \\
\hline Kidney & $33500 \pm 3200$ \\
Alimentary tract (whole) & $6500 \pm 600$ \\
Spleen (accessory spleen incl.) & $2000 \pm 180$ \\
Mucus & $1500 \pm 140$ \\
Serum & $1400 \pm 130$ \\
Gills & $1200 \pm 110$ \\
Liver & $660 \pm 60$ \\
Muscle & $390 \pm 36$ \\
\hline
\end{tabular}


that we, in contrast to Lindsay, did not differentiate between lymphoid rich and lymphoid poor regions of these particular tissues.

\section{Species variation}

Table 2 lists kidney lysozyme activities in the different species examined. Rainbow trout and sea char Salvelinus alpinus f. salvelinus showed high levels, together with turbot Scophthalmus maximus, halibut Hippoglossus hippoglossus, flounder Platichthys flesus, catfish Anarhichas Iupus and ocean perch Sebastes marinus. Most of the cod family members examined -

Table 2. Kidney lysozyme aclivity in the fish listed, measured by turbidimetric assay

\begin{tabular}{|lc|}
\hline Species & Lysozyme units $\mathrm{g}^{-1} \pm \mathrm{SE}$ \\
\hline Salmo gairdneri & $33500 \pm 3200$ \\
Salvelinus alpinus f. salvelinus & $10450 \pm 1600$ \\
Salmo trutta & $1550 \pm-^{\mathrm{a}}$ \\
Salmo salar & $2050 \pm 150$ \\
Hippoglossus hippoglossus & $22500 \pm-^{\mathrm{a}}$ \\
Scophthalmus maximus & $10750 \pm 4100$ \\
Platichthys flesus & $12500 \pm-^{\mathrm{a}}$ \\
Gadus morhua & $150 \pm 43$ \\
Melanogrammus aeglefinus & $950 \pm 430$ \\
Molva molva & $85 \pm 35$ \\
Brosme brosme & $40 \pm 14$ \\
Merluccius merluccius & $3300 \pm-{ }^{2}$ \\
Anarhichas lupus & $17650 \pm 4900$ \\
Sebastes marinus & $15300 \pm 3700$ \\
Galeorhinus galeus ${ }^{b}$ & - \\
a Species represented by only 1 individual each & - \\
b Weak activity detected by the more sensitive lysoplate \\
assay, but turbidimetric assay was negative for this \\
species
\end{tabular}

i.e. cod Gadus morhua, haddock Melanogrammus aeglefinus, ling Molva molva and tusk Brosme brosme exhibited low levels of kidney lysozyme activity. The data obtained reveal, in spite of the limited material, a reasonable distribution pattern among species seen in association with genetic relations (within the cod family), and environmental similarities (demersal fish).

The differences between rainbow trout and Atlantic salmon are of particular interest, since these are the main species farmed commercially in Norway. Furthermore, reduced lysozyme levels were measured in Atlantic salmon suffering from 'Hitra-disease' or cold-water vibriosis. This might result from an increased susceptibility to the disease due to inherent (genetically) reduced lysozyme levels, but a depressive effect of the disease on the lysozyme activity has to be considered, as well as postmortal degradation of the lysozyme.

\section{Concluding remarks}

The data obtained on tissue distribution, species variation, biochemical properties, and the in vitro antibacterial effect of fish lysozymes (Grinde unpubl.) are encouraging with regard to prospects for genetic improvement of lysozyme activity through selective breeding. The employment of modern tools, such as recombinant DNA technique, would also seem to be relevant, either in the bacterial production of lysozymes for therapeutic or prophylactic use, or in transgenic experiments aimed at creating enhanced or optimized lysozyme activity in fish, which would help them to withstand tough culture conditions. In such a way the strength of a 'natural' antibiotic could be potentiated, resulting in the creation of a sensible alternative to the antibiotics presently being employed in the aquaculture industry.

Acknowledgements. The authors are indebted to Dr Tore Håstein for kindly providing research material and for valuable discussions during the preparation of the manuscript. We also thank shipowner Peder $\mathrm{O}$. Lie who most generously provided kidney samples, free of charge, from wild fish species caught off the west coast of Norway. Financial support from the Agricultural Research Council of Norway is gratefully acknowledged

\section{LITERATURE CITED}

Baniahmad, A., Muller, M., Steiner, Ch., Renkawitz, R. (1987). Activity of two different silencer elements of the chicken lysozyme gene can be compensated by enhancer elements. The EMBO Journal 6: 2297-2303

Dobson, D. E., Prager, E. M., Wilson, A. C. (1984). Stomach lysozymes of ruminants. 1. Distribution and catalytic properties. J. biol. chem. 259: 11607-11613

Du Pasquier, L. (1982). Antibody diversity in lower vertebrates - why is it so restricted? Nature, Lond. 296: 311-313

Ellis, A. E. (1981). Stress and the modulation of defence mechanisms in fish. In: Pickering, A. D. (ed.) Stress and fish. Academic Press, London, p. 147-169

Ellis, A. E. (1982). Differences between the immune mechanisms of fish and higher vertebrates. In: Roberts, R. J. (ed.) Microbial diseases of fish. Academic Press, London, p. 1-29

Fänge, R., Lundblad, G., Lind, J. (1976). Lysozyme and chitinase in blood and lymphomyeloid tissues of marine fish. Mar. Biol. 36: 277-282

Ingram, G. A. (1980). Substances involved in the natural resistance of fish to infection - a review. Fish. Biol. 16: 23-60

Jolles, P., Jolles, J. (1984). What's new in lysozyme research? Always a model system, today as yesterday. Mol. Biochem. 63: 165-189

Lie, $\varnothing$., Solbu, H. (1983). Evidence for a major gene regulating serum lysozyme activity in cattle. Z. Tierz. Züchtungsbiol 100: $134-138$

Lie, ., Syed, M. (1986). Some properties of the lysozymes in serum and colostrum from cows with high and low lytic power against Micrococcus lysodeikticus. Anim. Genet. 17: $47-59$ 
Lie, Ø., Syed, M., Solbu, H. (1986). Improved agar plate assays of bovine lysozyme and haemolytic complement activity. Acta vet. scand. $27 \cdot 23-32$

Lindsay, G. J. H. (1986). The significance of chitinolytic enzymes and lysozyme in rainbow trout (Salmo gairdneri) defence. Aquaculture 51. 169-173

Lundblad, G., Fange, R., Slettengren, K., Lind, J. (1979) Lysozyme, chitinase and exo-N-acetyl- $\beta$-D-glucosaminidase (NAGase) in lymphomyeloid tissue of marine fishes. Mar. Biol. 53: 311-315

Matsunaga, T (1985). Evolution of antibody repertoire somatic mutation as a late comer. Develop. Comp. Immunol. 9: 585-596

Murray, C. K., Fletcher, T. C. (1976). The immunohistochemical localization of lysozyme in plaice (Pleuronectes platessa) tissue. J. Fish. Biol. 9: 329-334

Ossermann, E. F., Lawlor, D. P. (1966). Serum and urinary lysozyme (Muramidase) in monocytic and monomyelocytic leukemia. J. exp. Med. 124: 921-951

Parry, R. M., Chandau, R. C., Shahani, R. M. (1965). A rapid and sensitive assay of muramidase. Proc. Soc. exp. Biol. Med. 119: 384-386

Prager, E. M., Wilson, A. C. (1971). Multiple lysozymes of duck egg white. J. biol. Chem. 246: 523-530

Prieur, D. J., Camara, V M. (1979). Inheritance of lysozyme deficiency in rabbits. J. Hered. 70: 181-184

Steiner, Ch.، Muller, M., Baniahmad, A., Renkawitz, R. (1987). Lysozyme gene acting in chicken macrophages is controlled by positive and negative regulatory elements. Nucleic Acids Res. 15: 4163-4178

Theisen, M., Stief, A., Sippel, A. E. (1986). The lysozyme enhancer: cell specific activation of the chicken lysozyme gene by a far-upstream. DNA element. The EMBO Journal 5: 719-724.

Tonegawa, S. (1983). Somatic generation of antibody diversity. Nature, Lond. 302: 575-581

Virella, G. (1977). Electrophoresis of lysozyme into Micrococcus-containing agarose gel: quantitative analytical applications. Clin. chin. Acta 75: 107-115

Responsible Subject Editor: Dr G. Peters; accepted for printing on October 7, 1988 